\title{
IMPROVING COLLEGE STUDENTS' CRITICAL THINKING THROUGH THE USE OF A STORY TOOL FOR SELF-REGULATED LEARNING TRAINING
}

\author{
Pedro Rosário, José Carlos Núñez, Paula Magalhães, \\ Sonia Fuentes, Cleidilene Magalhães, and Kyle Busing
}

\section{Summary}

This chapter describes the efficacy of story tools for promoting self-regulated learning (SRL) and critical thinking, through a narrative-based approach. A voluminous corpus of research shows that students who receive training in SRL strategies (e.g., goal setting, time management, help seeking) are likely to engage deeply in school tasks, display higher-order thinking skills, and show high academic achievement. We present Letters from Gervase as a story-tool to improve SRL for 1st year college students. The program that utilizes this story-tool is aimed at promoting competencies (e.g., SRL strategies, critical thinking skills) through narratives. We present research evidence that demonstrates its effectiveness.

\section{Introduction}

Due to the rapid evolvement of contemporary societies, institutions and citizens face ongoing challenges that impact everyday modern day life and society (e.g., dwindling natural resources, evolving technology, and ongoing changes in social life). There is a need to address these challenges and display efforts to find paths for sustainable development and life-long learning; so, not surprisingly, people worldwide grapple with the need to train students, irrespective of their grade level, to be critical thinkers, and to be able to master the use of information in their work and daily life (Moore, 2013; Phan, 2010).

Schools and universities around the world are focused on responding to this universal call; and, among other efforts, university and school administrations ask teachers to teach their students to use critical thinking skills in class. 
Equipping students with critical thinking skills (e.g., analytical thinking approach, inference making, and argumentation skills) is expected to prepare them for lifelong learning and active citizenship (Hammer \& Green, 2011; Moore, 2013; Phan, 2010).

Critical thinking has a complex construct and literature offers several definitions that vary in nature and scope (Yanchar, Slife, \& Warne, 2008). For example, Ennis (1989, p. 4) defines critical thinking as "reasonable reflective thinking focused on deciding what to believe or do," while Bailin and colleagues understand critical thinking as "thinking aimed at forming a judgment" (Bailin, Case, Coombs, \& Daniels, 1999, p. 287).

Despite the differences in the approach to the concept, in general, researchers agree that students who master critical thinking skills are likely to understand knowledge as worth pursuing, and to value knowledge as an important tool to reach robust problem-solving analysis, solid conclusions, and evidence-based decisions (Ennis 1987; Paul \& Elder, 2012). However, as Johnson (2000) prudently advises, a critical thinking student is expected to be a skilled thinker, but being a skilled thinker is not enough to cope with persistent personal and societal demands. In fact, using a set of critical skills in class does not assure, by itself, that a student will meet societal expectations for professional performance.

In sum, following this line of reasoning, we may ask: is critical thinking limited to the use of a set of organized and skillful approaches to content knowledge? For example, Lau (2015), alerts educators and researchers that critical thinking requires the ability to reflect critically on the reasons for judgment and goes beyond the use of cognitive and thinking skills in class. He stresses the need to include a reflection approach that acknowledges the role of metacognition in students' training (see Flavell, 1979).

\section{The case of self-regulated learning}

Lau's (2015) assertions echo those proposed by Dewey early in the 20th century. Dewey (1933) emphasized the need to approach an idea "in light of the grounds that support it and the further conclusions to which it tends" (p. 7). Moreover, he argued that students need more than a robust corpus of knowledge to develop thinking skills. According to Dewey (1933), "reflective thinking, in distinction from other operations to which we apply the name of thought, involves (1) a state of doubt, hesitation, perplexity, mental difficulty, in which thinking originates, and (2) an act of searching, hunting, inquiring, to find material that will resolve the doubt, settle and dispose of the perplexity" (p. 12).

To master critical thinking, students are expected to develop a focused, self-disciplined (Paul, 1993), diligent and persistent approach (Facione, 1990) to acquire knowledge. In sum, students need to master self-regulation competencies, and we believe that the framework of self-regulation provides a relevant theoretical framework to the promotion of critical thinking citizens. 


\section{Brief introduction to SRL}

Self-regulated learning (SRL) is an active process where students set goals that are likely to direct their learning and monitor, regulate, and control cognitions, as well as motivations and behaviors, with the purpose of achieving self-set goals (Fulano, Cunha, Núñez, Pereira, \& Rosário, 2018; Rosário, Núñez, \& González-Pienda, 2006; Zimmerman, 2002). Selfregulated learning occurs when students exert their efforts to focus their beliefs, thoughts and actions on their educational goals (Phan, 2010; Schunk, 1987, 2001).

Students who self-regulate their learning display cognitive and metacognitive processes to control their cognition, motivation, learning environments, and behaviors (Zimmerman \& Schunk, 2011), before, during, and after learning (Rosário, Núñez, Valle, González-Pienda, \& Lourenço, 2013; Zimmerman, 2000). These students are inclined to view learning as an activity to help them develop proactively rather than reactively in response to teaching (Zimmerman, 2002; Zimmerman, Greenberg, \& Weinstein, 1994). Moreover, students who self-regulate their learning are likely to use learning strategies, and approach content knowledge in flexible and meaningful ways, through understanding the task, evaluating data and considering multiple perspectives to approach it (VanderStoep \& Pintrich, 2003). These students typically engage in learning using a deeper learning approach; they constantly reflect on their learning behaviors and adjust them accordingly in search of meaning (Garrison \& Cleveland-Innes, 2005). For example, students using deeper learning approaches are more able than their counterparts to identify potential obstacles and select strategies to attain their learning goals (Davison \& Sternberg, 1998).

While learning, proficient students who use self-regulated learning strategies and deeper approaches to learning will actively seek the information needed and take necessary steps to acquire it (Paris \& Oka, 1986). Their focus is on assigning meaning to content knowledge. During this process, students are aware of their thinking processes and display self-regulatory control over their cognitions (Zimmerman, 1995). These metacognitive efforts to understand and assign meaning to learning play a crucial role in the development of an individual's critical thinking (Wineburg, 1997); in fact, metacognition is one of the strongest predictors of critical thinking (Ingle, 2007).

In sum, students who master SRL focus on their agent role and assume that academic success is a byproduct of their own behaviors (Bandura, 2001). Not surprisingly, there is a voluminous corpus of data stressing the close relationships between SRL, motivation for learning and academic success (e.g., Boekaerts \& Corno, 2005; Núñez et al., 2011; Rosário et al., 2010; Valle et al., 2016; Zimmerman \& Martínez-Pons, 1988; Zimmerman \& Schunk, 2008), as well as literature relating SRL with the individual's development of critical thinking (Brown \& Campione, 1994; Zimmerman, 1990). 


\section{SRL story-tools line of research}

The SRL story-tools line of research was developed in Portugal, at the University of Minho, in collaboration with researchers from the University of Oviedo in Spain. This research line addresses the promotion of SRL through stories. In recent years, investigators from Chile, Brazil, Mexico, Mozambique, Japan, and United States have been incorporated into the research team (e.g., Rosário et al., 2014). Encouraged by the need to build evidence-based intervention tools fit for students' SRL needs, school teachers, faculty, and investigators have worked together to build story-tools aimed at promoting SRL. Over the last two decades, the research team developed a set of story-tools ${ }^{1}$ aimed at promoting SRL throughout schooling as follows: Yellow trials and tribulations (Rosário, Núñez, \& González-Pienda, 2007) for elementary school; Collection of Testas' (mis)adventures (Rosário, 2002a, 2002b, 2002c; 2003; 2004a, 2004b) for 5ththrough 9th-graders; and finally, Letters from Gervase (Rosário et al., 2006) for first-year college students.

\section{General features of the SRL story-tools programs}

SRL, from the perspective of Zimmerman (2000, 2002), is understood as an open and dynamic process that proceeds through three main phases: forethought, performance or volitional control phase, and self-reflection. These phases of the SRL process interact dynamically and follow a sequential loop (Rosário, et al., 2014; Zimmerman, 2008). Within the SRL framework, these processes are cyclic and interdependent; the forethought phase informs the volitional control phase, which influences the processes of the self-reflection phase. Each of these processes impact the following phase, shaping students learning process (Rosário et al., 2010; Zimmerman, 2000). For this reason, students are expected to understand the nature and functioning of this learning and assume agency and responsibility of their SRL process. The research literature reports that high-achieving students when compared with low achievers are more likely to use learning strategies purposefully to attain their learning goals (Zimmerman \& Martínez-Pons, 1986, 1988).

Our SRL story-tools programs are designed to foster students' SRL strategies by using narratives. Narratives are the main tool for organizing our concept of time. It corresponds to the representation of an event or series of events clustered around some meaning. In this sense, stories do more than inform or instruct, they make us who we are. In one of his first books about learning and instruction, Bruner (1986) presents narrative ways of thinking as an alternative way of facing reality. He defends his narrative as a universal path used by all cultures, albeit with different matrices, to align experiences and assign meaning. Tales and stories invite people to look inside themselves, reflect about their own behaviors and subsequent consequences as long as they can identify with the story's characters and their dilemmas, choices, and narrated adventures. As noted earlier, 
reflection on one's own behaviors and reasons for judgment are a necessary element for effective critical thinking. (Lau, 2015).

In the above-mentioned story-tools programs, students are prompted to build their own meanings, their own understanding of the SRL narrative, to reach the target conditional learning (i.e., learn how to respond appropriately to a situation requiring self-regulatory skills), and to transfer those skills learned and discussed in class to other academic domains or own life. As Rosário (2004a) stated, "we don't learn when we are taught or when we listen, but rather when we adopt, recreate and appropriate meanings. Learning is always an author's task" (p. 11). Through a guided analysis of a narrative, children and young people may be instigated to articulate their knowledge of SRL reasoning about characters' behaviors and their own.

Students, regardless of their age, often learn vicariously by observing other people's actions directly or indirectly (e.g., in movies, on television, on the Internet, and by reading books; Zimmerman \& Schunk, 2001). In this sense, the social cognitive framework - stressing that not all human learning arises from direct experience - describes how observing others' behaviors and the resulting rewards or punishments can organize and motivate the observers' behavior (Bandura, 2001). Modeling refers to the process through which observers pattern their own thoughts, beliefs, strategies, and actions after observing models (Schunk, 2001). Modeling is an important way to develop competencies, beliefs, attitudes, and behaviors. Teachers, parents, other adults, and peers become, therefore, powerful models for the learners. Behaviors, verbal utterances, and even nonverbal expressions of significant models can be considered by the observers as prompting cues for subsequent reproduction (Bandura, 1986).

Furthermore, modeling provides informative and motivational sources. Observing competent models perform actions successfully can provide individuals with useful information regarding the sequence of actions to follow, in the hope of obtaining the same results (Craig, Sullins, Witherspoon, \& Gholson, 2006). However, Schunk (1987) argued that the simple observation of a model performing a task (e.g., a friend, colleague, teacher, or parent), is not enough to encourage the observer to perform it, regardless of how competent the model could have been. For this type of learning to be effective, it is important for individuals to perceive similarities between themselves and the model. In the modeling process, this is one of the most relevant motivational variables for a successful outcome. Perceived similarity with the model is a fundamental aspect of judging one's own efficacy. For example, by observing peers experiencing success, college students are likely to develop self-efficacy beliefs and become more motivated to perform the task. The opposite also holds true. When college students observe their peers being unsuccessful, they are less likely to allocate effort toward accomplishing the task. The SRL processes and strategies already mentioned (e.g., time management, organizing information, monitoring progress) could be taught by social models (Zimmerman, 2008). Students using vicarious learning can acquire not only declarative knowledge regarding the nature of the learning strategies but 
also procedural and conditional knowledge that can be useful tools for future independent learning.

\section{Detailed description of SRL story-tools programs}

This section is intended to briefly analyze each instructional program and their components. We describe and analyze the specific features of the learning and teaching activities to explain their rationale and purpose. We also offer specific examples from the narratives and practical tasks that will help readers understand how the story-tools projects can be run.

A main goal of the SRL training is to help students' master three types of knowledge about learning strategies: declarative, procedural, and conditional (Núñez et al., 2013; Rosário et al., 2017). Declarative knowledge of learning strategies is factual knowledge that involves information on a variety of learning strategies (e.g., know what time management is). Procedural knowledge of learning strategies is the knowledge of how to implement the learning strategies (e.g., know how to use time management tools to attain goals). Finally, conditional knowledge explains when individuals should use a learning strategy in a specific learning context (e.g., reflect on the difference between use and loss of time and act accordingly to decide when to approach a task) (Alexander, 2006).

Students engage in a hands-on approach: they are presented with a set of SRL strategies (see, Rosário et al., 2010, 2014; Weinstein, Husman \& Dierking, 2000; Zimmerman \& Martínez -Pons, 1986) and are asked to decide what, how, and when to use each. We believe this active methodology is likely to help students become aware of their agent role as learners, and effectively focus their attention on the contents to be learned (Rosário et al., 2007; Weinstein et al., 2000). Our ultimate goal is to develop effective thinking using SRL embedded in a story tool.

In each session of this story-tool program, and for each SRL strategy, students are asked to discuss declarative, procedural, and conditional knowledge (e.g., goal-setting, strategies for revision, strategies for organizing information). Moreover, instructors use vicarious learning to help students reflect upon declarative, procedural, and conditional knowledge of these learning strategies across diverse learning contexts (e.g., academic situations, preparing for and taking tests, and completing homework). The fostering and mediating of students' learning transfer will likely help deepen their understanding of the strategies and encourage their use in contexts other than learning (e.g., organizing their sports training sessions, organizing judgments in their interpersonal relationships).

All our story-tools follow an instructional sequence that can be summarized in three steps: reading of the chapter/letter, reflection about the narrative content, and, finally, work on practical tasks. The instructors guide discussions and explain by exemplifying how students could expand their strategy repertoire. Aiming to promote lifelong learning skills, instructors are expected to facilitate students' agency and personal control and help them reflect on and anticipate the consequences of action. 


\section{Letters from Gervase (promoting SRL in first-year college students)}

The Letters from Gervase target first-year college students during their process of adapting to college life. The book is comprised of 13 texts, drafted as letters written by Gervase, a first-year university student (Pina, Rosário, \& Tejada, 2010; Rosário et al., 2006; Rosário, Fuentes, Beuchat \& Ramaciotti, 2016). Using a casual, friendly, and humorous style, Gervase writes about the experiences he faces as a first-year college student (e.g., reflections about the SRL processes and learning strategies, academic adaptation process, and other academic and social challenges).

This tool has a flexible nature and can be adapted to the needs of the students and the demands of the learning contexts. For example, there is no mandatory protocol, or an optimal number of sessions required. However, prior research (see Table 11.2) shows that programs should use at least six letters, one for each session. The sessions, lasting from 60 to 90 minutes, can be mediated by an instructor in class, in an extracurricular course, or even by a counselor in individual work sessions. It is also possible to use the program in e-learning settings (see, Cerezo et al., 2010; Núñez et al., 2011).

Each letter is organized around a repertoire of learning strategies set by Zimmerman and Martínez-Pons in 1986 (e.g., goal setting, organization and transformation of information, taking notes, information seeking) that correspond to the three phases of the SRL process (e.g., forethought phase, performance phase, and self-reflection phase; Zimmerman, 2002; see Table 11.1). In addition, the project manual presents a set of activities to help individuals reflect on the narrative and apply study and SRL strategies to distinct learning scenarios (Rosário et al., 2007, 2010, 2014, 2016).

This story-based tool was designed to promote students' analysis of the contents of the letters, followed by the discussion of the embedded SRL strategies with the help of an instructor. For example, during the sessions the participants discussed the contents, the presented strategies, and SRL processes through the narrative, aiming at fostering a deeper approach to learning and the development of a critical approach to thinking.

College students are invited to analyze the information in the letters, analyze and select the relevant information, and, finally, transfer this knowledge to their academic and personal lives.

In sum, working with this story-based tool provides students with the opportunity to reflect on their own learning processes, both at an individual and at a group level, with the aim of fostering their metacognition, motivation, and academic engagement.

As previously stated, the Letters from Gervase program does not provide sessions of a rigid structure, nor prescribed times to develop the suggested activities. Sessions are a vehicle to work self-regulation skills in the classroom, with a flexible nature adjustable to the speed and needs of the different readers/authors. Typically, each session is organized in four steps as described here. (1) First, and for about 15 minutes, the students read and analyze the assigned letter silently and 
TABLE 11.1 Contents and SRL strategies included in a sample of Letters from Gervase story-tool

Sample of letters in the Letters from Gervase story-tool project

Contents and self-regulating strategies addressed

Letter 1 - What does it mean, after all, adjusting to university life?

Letter 2 -What are my goals? What really guides my actions at all levels, i.e., my studies, my university attendance, my hobbies, sports and relationship with others... and even my lassitude?

Letter 3 - How can I take better notes?

Letter 4 - Do you know how to fight procrastination, Gervase?

Letter 6 - Who rules your learning? How can one tell successful students apart?

Letter $12-$ What is test anxiety? How can one deal with test anxiety?
Adaptation to university.

Planning and time management.

Setting goals.

Rules of goal setting.

Concrete Realistic Assessable (CRAss).

Short-term and long-term goals.

Study goals and achievement goals.

Organizing information: summaries, tables, diagrams and conceptual maps...

Note-taking.

Controlling distractions.

Time management.

"To do" lists.

Organizing the study environment.

Procrastination.

Relaxation techniques.

SRL.

The Cyclical model of SRL

(see Zimmerman, 2008).

Setting goals.

Monitoring.

Motivation.

Test anxiety.

Aspects of anxiety (feelings and emotions). Internal and external distractors.

Plagiarism and copy write.

Relaxation techniques.

individually, hopefully taking notes. (2) Then, for about 45 minutes, students work in small groups to encourage the exchange of ideas, promote problem solving, and foster teamwork. Modeling, strategy learning, and reflection on the SRL strategies embedded in the letters are examples of the tools used in the sessions to transfer the new knowledge to the academic domains and daily life activities. The tasks proposed to the students are expected to be selected from a pool of activities presented in the manual of the program. For example, students discuss in the sessions that critical thinking is activated when students orchestrate a set of cognitive strategies to approach learning. To practice their critical thinking skills (e.g., Interpretation-Categorization, Clarifying Meaning; and Analysis: Examining Ideas, Identifying Arguments, Analyzing Arguments), students can be encouraged to write a draft of a newspaper advertisement aimed at selecting the most suitable candidate for a course on [a specified topic area] (cf. Rosário et al., 2006). (3) Afterwards, for about 20 minutes, each group of students shares their written drafts with the other groups and are given the opportunity to 
discuss ideas, ask questions, clarify information, and pose challenges to their classmates' thoughts. (4) Finally, for about 10 minutes, the instructor delivers a take home message comprising of a short summary of the major topics discussed.

Some examples of take-home messages, as well as of activities to be developed by the students during the sessions are provided in the manual of the project (Rosário et al., 2006). The activities can be selected from a recommended pool, or developed with the purpose of intervention while considering the students' goals, learning needs, their expertise on SRL, mastery of critical thinking skills, and academic proficiency.

\section{Extant research with Letters from Gervase story tool}

Examples of research studies that have used the story tool Letter from Gervase are summarized in Table 11.2. The corpus of findings gathered from this research provides grounds for the conclusion that this story-tool is efficacious for improving SRL strategies, critical thinking skills, and academic performance at college.

\section{Conclusions}

There is an open call for proactive school-based interventions aimed at promoting learning strategies and metacognitive skills. In fact, literature reviews on SRL (e.g., Boekaerts \& Corno, 2005; Dignath, Buettner, \& Langfeldt, 2008) suggest the need to find ways of promoting SRL in educational settings and highlighting students' proactive role (e.g., students' willingness to inquire). Therefore, faculty and college administrators could consider increasing the number of programs to improve SRL in colleges (Rosário, et al., 2014; Rosário et al., 2016). Training SRL competencies is likely to help students analyze information, ask and answer questions to clarify data, and reach a solution to a problem (see Boekaerts \& Corno, 2005). This process requires development of self-judgment and reflection from students, and ultimately this will foster their critical thinking.

Following the SRL literature, we can understand critical thinking as the ability to use acquired knowledge in flexible and meaningful ways by considering multiple perspectives to approach the task or solve problems (VanderStoep \& Pintrich, 2003). This perspective is consistent with the literature on critical thinking which defines critical thinkers as people who are "habitually inquisitive, well-informed, trustful of reason, open-minded, flexible, fair-minded in evaluation, honest in facing personal biases, prudent in making judgments, willing to reconsider, clear about issues, orderly in complex matters, diligent in seeking relevant information, reasonable in the selection of criteria, focused in inquiry, and persistent in seeking results" (Facione, 1990, p. 9).

Leung and Kember (2003) advocate that critical thinking is a cognitive tool that helps students further examine their learning material by using deep strategies. Moreover, Kuiper (2002) found that critical thinking skills help to facilitate the transfer of learning strategies to other learning contexts. In fact, consistent 


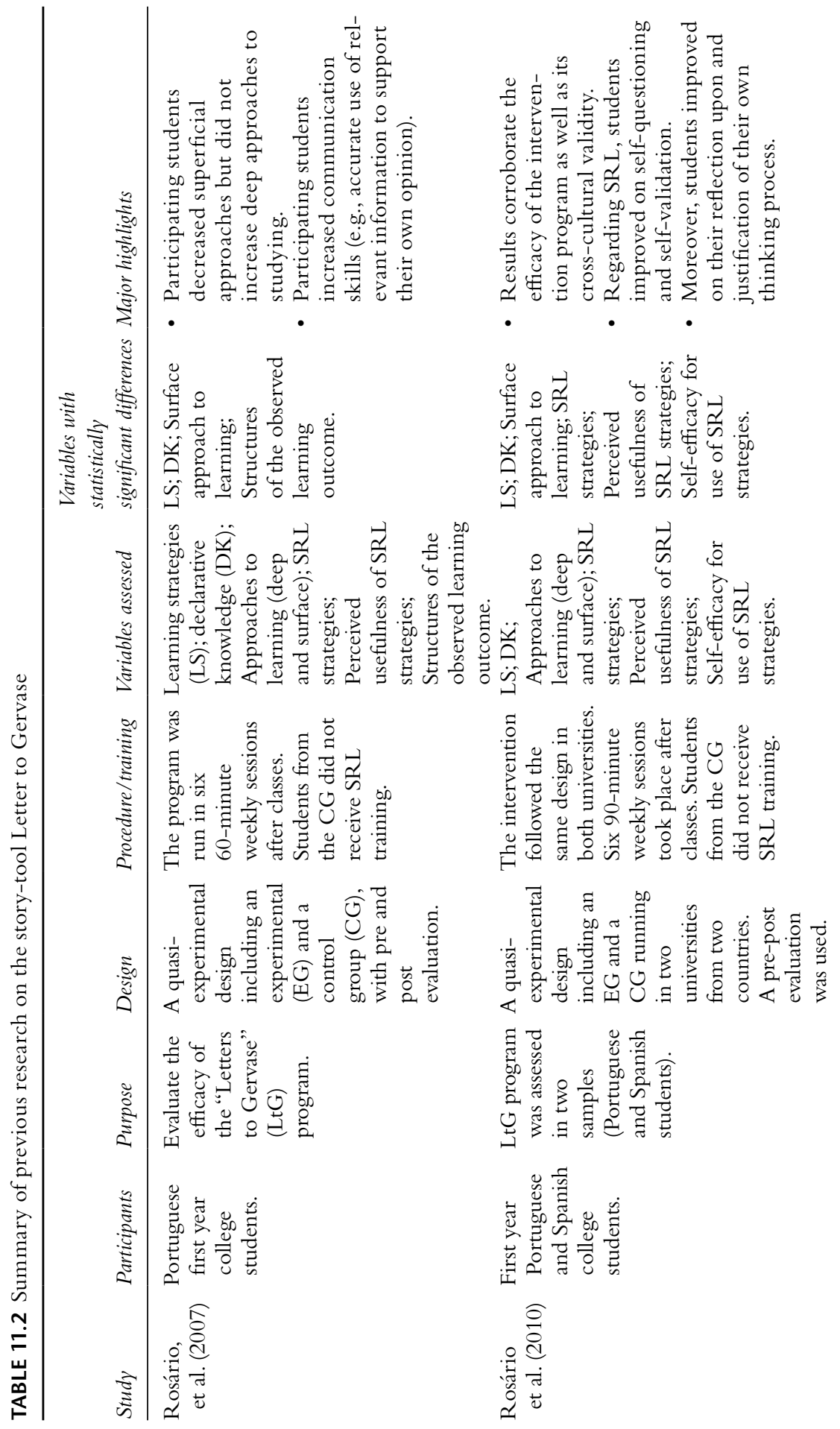




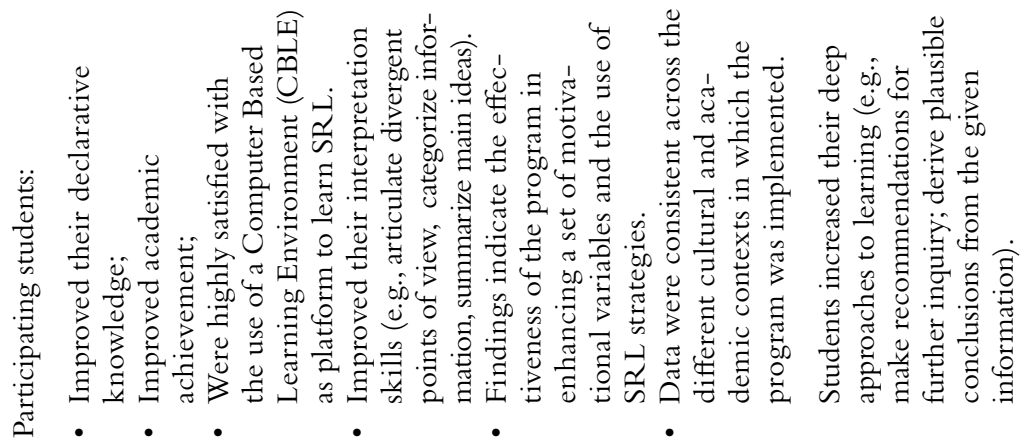

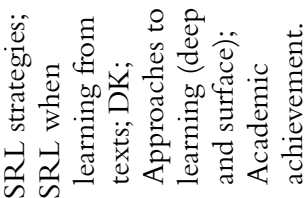

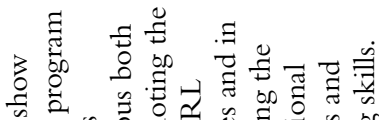

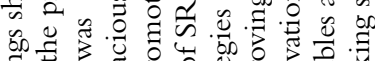

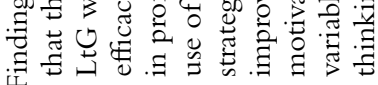

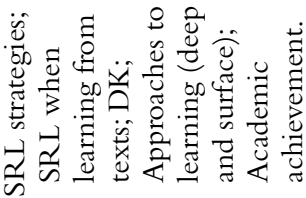

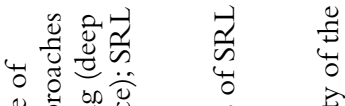

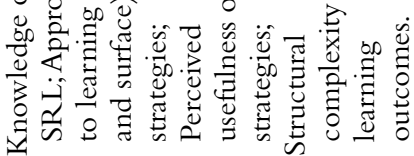

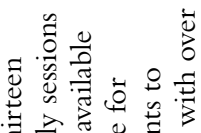

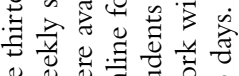

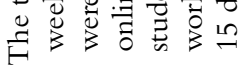

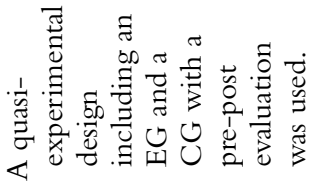

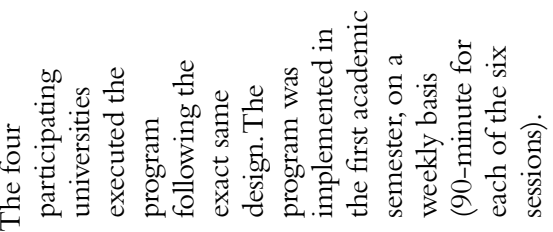

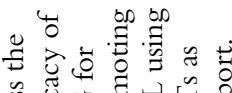

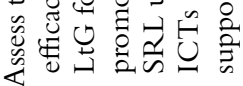

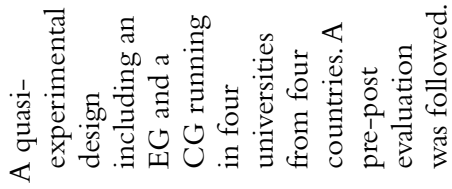

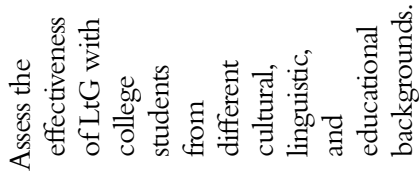

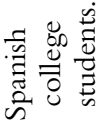

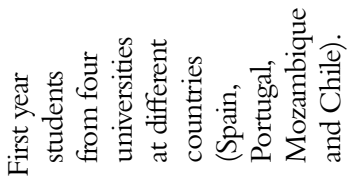

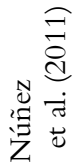

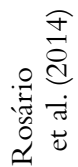


with these propositions, the extant research shows that while using critical thinking to solve problems or understand new content, students need to manage prior information by excelling in the use of learning strategies (Zimmerman, 2008).

We believe that the SRL contents discussed throughout Letters to Gervase meet students' expectations, immediate academic challenges (e.g., time management, procrastination, note-taking, academic distracters, and goal setting), and their critical thinking needs (e.g., training in questioning evidence; awareness of the need to consider multiple perspectives prior to taking a position; communication strategies; awareness of what, why, how, and when people understand and display feelings about something). Note that due to space constraints we are only able to introduce the Letters to Gervase program, but - as noted earlier - there are equivalent story tools for younger students, which have also been demonstrated to be effective in several research studies (e.g., Núñez, Rosário, Vallejo, \& GonzálezPienda, 2013; Rosário, Núñez, Rodríguez, et al., 2017; Rosário, Núñez, Vallejo, et al., 2017). The training on thinking skills and deep learning strategies provides students with valuable expertise to analyze and evaluate information and avoid misconstrued and biased information based on ad hoc opinions and common knowledge (e.g., filter, calibrate and select information on social media). This sense of usefulness and mastery of one's critical thinking may predispose students to display an agent role in their learning process. Globally, our SRL story-tools program has proven to be a positive educational tool to promote learning strategies, deeper approaches to learning, and ultimately critical thinking.

However, despite the promising results of our line of research, more investigations are needed to further examine the development of critical thinking skills through the training on SRL strategies. For example, training students to ask questions to clarify information would likely help students built a robust argument. Moreover, analyzing the efforts made by students on their time management, and discussing the consequences of using or losing time may help develop students' skills of reflection.

\section{Note}

1 The references list contains the information for the Portuguese and Spanish books for the story tools; readers can email the first author for English versions of the story-tools.

\section{References}

Alexander, P. A. (2006). Psychology in learning and instruction. Upper Saddle River, NJ: Pearson Merrill Prentice Hall.

Bailin, S., Case, R., Coombs, J. R., \& Daniels, L. B. (1999). Conceptualizing critical thinking. Journal of Curriculum Studies, 31(3), 285-302.

Bandura, A. (1986). Social foundations of thought and action: A social cognitive theory. Englewood Cliffs, NJ: Prentice-Hall.

Bandura, A. (2001). Social cognitive theory: An agentic perspective. American Review of Psychology, 52, 1-26. 
Boekaerts, M., \& Corno, L. (2005). Self-regulation in the classroom: A perspective on assessment and intervention. Applied Psychology: An International Review, 54(82), 199-231.

Brown, A. L., \& Campione, J. C. (1994). Guided discovery in a community of learners. In K. McGilly (Ed.), Classroom lessons: Integrating cognitive theory and classroom practice (pp. 229-270). Cambridge: MA: MIT Press/Bradford Book.

Bruner, J. (1986). Actual minds, possible worlds. Cambridge, MA: Harvard University Press.

Cerezo, R., Núñez, J. C., Rosário, P., Valle, A., Rodriguez, S., \& Bernardo, A. (2010). New media for the promotion of self-regulated learning in higher education. Psicothema, 22(2), 306-315.

Craig, S., Sullins, J., Witherspoon, A., \& Gholson, B. (2006). Deep-level reasoning questions effect: The role of dialog and deep-level reasoning questions during vicarious learning. Cognition and Instruction, 24(4), 565-591.

Davison, J. E., \& Sternberg, R. J. (1998). Smart problem solving: How metacognition helps. In D. J. Hacker, J. Dunlosky, \& A. C. Grasser (Eds.), Metacognition in educational theory and practice (pp. 47-68). Mahwah, NJ: Lawrence Erlbaum.

Dewey, J. (1933). How we think: A restatement of the relation of reflective thinking to the educative process. Boston, MA: D. C. Heath.

Dignath, C., Buettner, G., \& Langfeldt, H. (2008). How can primary school students learn SRL strategies most effectively? A meta-analysis on self-regulation training programmes. Educational Research Review, 3, 101-129.

Ennis, R. H. (1987). A taxonomy of critical thinking dispositions and abilities. In J. B. Baron \& R. J. Sternberg (Eds.), Teaching thinking skills: Theory and practice (pp. 9-26). New York: W. H. Freeman.

Ennis, R. H. (1989). Critical thinking and subject specificity: Clarification and needed research. Educational Researcher, 18(3), 4-10.

Facione, P. (1990). The Delphi Report: Critical thinking: A statement of expert consensus for purposes of educational assessment and instruction. Millbrae, CA:Academic Press.

Flavell, J. H. (1979). Metacognition and cognitive monitoring: A new area of cognitivedevelopmental inquiry. American Psychologist, 34(10), 906.

Fulano, C., Cunha, J., Núñez, J. C., Pereira, B., \& Rosário, P. (2018). Mozambican adolescents' perspectives on the academic procrastination process. School Psychology International, 39 , 196-213.

Garrison, D. R., \& Cleveland-Innes, M. (2005). Facilitating cognitive presence in online learning: Interaction is not enough. The American Journal of Distance Education, 19(3), 133-148.

Hammer, S., \& Green, W. (2011). Critical thinking in a first year management unit: The relationship between disciplinary learning, academic literacy and learning progression. Higher Education Research and Development, 30(3), 303-316.

Ingle, C. (2007). Predictors of critical thinking ability among college students. PhD dissertation, University of Kentucky, United States - Kentucky. Retrieved October 8, 2008, from Dissertations \& Theses: Full Text. (Publication No. AAT 3263681).

Johnson, R. H. (2000). Manifest rationality: A pragmatic theory of argument. Mahwah, NJ: Erlbaum.

Kuiper, R. (2002). Enhancing metacognition through the reflective use of self-regulated learning strategies. The Journal of Continuing Education in Nursing, 33(2), 78-87.

Lau, J. (2015). Metacognitive education: Going beyond critical thinking, In M. Davies \& R. Barnett (Eds). The Palgrave handbook of critical thinking in higher education (pp. 373-390). New York: Palgrave Macmillan.

Leung, D.Y.P., \& Kember, D. (2003). The relationship between approaches to learning and reflection upon practice. Educational Psychology, 23(1), 61-71.

Moore, T. (2013). Critical thinking: Seven definitions in search of a concept. Studies in Higher Education, 38(4), 506-522. 
Núñez,J. C., Cerezo, R., González-Pienda,J.A., Rosário, P.,Valle,A., Fernández, E., \& Suárez, N. (2011). Implementation of training programs in self-regulated learning strategies in Moodle format: Results of an experience in higher education. Psicothema, 23, 274-281.

Núñez,J. C., Rosário, P.,Vallejo, G., \& González-Pienda,J.A. (2013).A longitudinal assessment of the effectiveness of a school-based mentoring program in middle school. Contemporary Educational Psychology, 38, 11-21.

Paris, S. G., \& Oka, E. (1986). Children's reading strategies, metacognition and motivation. Developmental Review, 6, 25-86.

Paul, R. (1993). Critical thinking: How to prepare students for a rapidly changing world. Santa Rosa, CA: Foundation for Critical Thinking.

Paul, R. W., \& Elder, L. (2012). Critical thinking: Tools for taking charge of your learning and your life (3rd ed.). Boston, MA: Pearson Education.

Phan, H. (2010). Critical thinking as a self-regulatory process component in teaching and learning. Psicothema, 22(2), 284-292.

Pina, F., Rosário, P., \& Tejada, J. (2010). Impacto de un programa de autorregulación del aprendizaje en estudiantes de Grado. Revista de Educación, 353, 571-588.

Rosário, P. (2002a). 007. ${ }^{\circ}$ Ordem para estudar [007th Order to study]. Porto, Portugal: Porto Editora.

Rosário, P. (2002b). Elementar, meu caro Testas [Elemental, my dear Sparky]. Porto, Portugal: Porto Editora.

Rosário, P. (2002c). Testas para sempre [Sparky forever]. Porto, Portugal: Porto Editora.

Rosário, P. (2003). O Senhor aos papéis, a irmandade do granel [Lord of trouble, the brotherhood of the caos]. Porto, Portugal: Porto Editora.

Rosário, P. (2004a). Estudar o Estudar: As (Des)venturas do Testas [Studying study: Sparky's (mis) adventures]. Porto, Portugal: Porto Editora.

Rosário, P. (2004b). Testas o Lusitano [Sparky the Luso]. Porto, Portugal: Porto Editora.

Rosário, P., Pereira, A., Högemann, J., Nunes, A. R., Figueiredo, M., Núñez, J. C., Fuentes, S., \& Gaeta, M. (2014). Self-regulated learning: A systematic review based in scielo journals. Universitas Psychologica, 13(2), 781-798.

Rosário, P., Fuentes, S., Beuchat, M., \& Ramaciotti, A. (2016). Self-regulated learning in a college classroom: A curriculum infusion approach. Revista de Investigación Educativa, 1, 31-49.

Rosário, P., González-Pienda, J. A., Pinto, R., Ferreira, P., Lourenço, A. \& Paiva, O. (2010). Efficacy of the program "Testas's (mis)adventures" to promote the deep approach to learning. Psicothema, 22(4), 828-834.

Rosário, P., Mourão, R., Núñez, J. C., González-Pienda, J. A., Solano, P., \& Valle, A. (2007). Evaluating the efficacy of a program to enhance college students' self-regulation learning processes and learning strategies. Psicothema, 19(3), 353-358.

Rosário, P., Núñez, J. C., Rodríguez, C., Cerezo, R., Fernández, E., Tuero, E., \& Högemann, J. (2017). Analysis of instructional programs for improving self-regulated learning SRL through written text. In R. Fidalgo, K. R. Harris, \& M. Braasksma (Eds.), Design principles for teaching effective writing: Theoretical and empirical grounded principles (pp. 201-231). Leiden, The Netherlands: Brill Editions.

Rosário, P., Núñez, J. C., Trigo, L., Guimarães, C., Fernández, E., Cerezo, R., Fuentes, S., Orellana, M., Santibáñez, A., Fulano, C., Ferreira, A., Figueiredo, M. (2014). Transcultural analysis of the effectiveness of a program to promote self-regulated learning in Mozambique, Chile, Portugal, and Spain. Higher Education Research and Development, 34(1), 173-187.

Rosário, P., Núñez, J. C., Valle, A., González-Pienda, J.A., \& Lourenço, A. (2013). Grade level, study time, and grade retention and their effects on motivation, self-regulated learning 
strategies, and mathematics achievement: A structural equation model. European Journal of Psychology of Education, 28(4), 1311-1331.

Rosário, P., Núñez, J.C., \& González-Pienda, J. A. (2006). Cartas do gervásio ao seu umbigo. Comprometer-se com o estudar na universidade [Letters from gervase to his belly button. Committing with studying at university]. Coimbra, Portugal: Almedina Editores.

Rosário, P., Núñez, J. C., \& González-Pienda, J.A. (2007). Sarilhos do amarelo [Yellow's trials and tribulations]. Porto, Portugal: Porto Editora.

Rosário, P., Núñez, J. C., González-Pienda, J. A., Valle, A., Trigo, L., \& Guimarães, C. (2010). Enhancing self-regulation and approaches to learning in first-year college students: A narrative-based program assessed in the Iberian Peninsula. European Journal of Psychology of Education, 25, 411-428.

Rosário, P., Núñez, J.C., Vallejo, G., Azevedo, R., Pereira, R., Moreira, T., Fuentes, S., \& Valle, A. (2017). Promoting Gypsy children's behavioural engagement and school success: Evidence from a four-wave longitudinal study. British Educational Research Journal, 43(3), 554-571.

Schunk, D. (1987). Peer models and children's behavioral change. Review of Educational Research, 57, 149-174.

Schunk, D. (2001). Social cognitive theory and self-regulated learning. In B. Zimmerman \& D. Schunk (Eds.), Self-regulated learning and achievement: Theoretical perspectives (2nd ed., pp. 125-151). Mahwah, NJ: Erlbaum.

Valle,A., Regueiro, B., Núñez J.C., Rodríguez, S., Piñeiro, I., \& Rosário, P. (2016). Academic goals, student homework engagement, and academic achievement in elementary school. Frontiers in Psychology, 7, 463.

VanderStoep, S. W., \& Pintrich, P. R. (2003). Learning to learn:The skill and will of college success. Upper Saddle River, NJ: Prentice Hall.

Weinstein, C. E., Husman, J., \& Dierking, D. (2000). Self-regulation intervention with a focus on learning strategies. In M. Boekaerts, P. Pintrich, \& M. Zeidner (Eds.), Handbook of self-regulation (pp. 727-747). New York, San Diego: Academic Press.

Wineburg, S. (1997). Reading Abraham Lincoln: An expert study in the interpretation of historical texts. Cognitive Science, 22(3), 319-346.

Yanchar, S. C., Slife, B. D., \& Warne, R. (2008). Critical thinking as disciplinary practice. Review of General Psychology, 12(3), 265-281.

Zimmerman, B. (1990). Self-regulated learning and academic achievement: An overview. Educational Psychologist, 25(1), 3-17.

Zimmerman, B. (1995). Self-regulation involves more than metacognition: A social cognitive perspective. Educational Psychologist, 30(4), 217-221.

Zimmerman, B. J. (2000). Attaining self-regulation. A social cognitive perspective. In M. Boekaerts, P. Pintrich, \& M. Zeidner (Eds.), Handbook of self-regulation (pp. 13-39). San Diego, CA:Academic Press.

Zimmerman, B. J. (2002). Becoming a self-regulated learner: An overview. Theory into Practice, 41(2), 64-70.

Zimmerman, B. J., \& Schunk, D. H. (2001). Self-regulated learning and academic achievement: Theoretical perspectives. Mahwah, NJ: Lawrence Erlbaum.

Zimmerman, B. J., \& Schunk, D. H. (2008). Motivation: An essential dimension of self-regulated learning. In D. H. Schunk \& B. J. Zimmerman (Eds.), Motivation and self-regulated learning: Theory, research, and applications (pp. 1-30). Mahwah, NJ: Lawrence Erlbaum.

Zimmerman, B. J., \& Schunk, D. H. (2011). Self-regulated learning and performance: An introduction and an overview. In B. J. Zimmerman \& D. H. Schunk (Eds.), Handbook of self-regulation of learning and performance (pp. 1-15). New York: Routledge. 


\section{Rosário, Núñez, Magalhães, et al.}

Zimmerman, B. J. (2008). Investigating self-regulation and motivation: Historical, background, methodological developments, and future prospects. American Educational Research Journal, 45, 166-183.

Zimmerman, B. J., \& Martínez-Pons, M. (1986). Development of a structured interview for assessing student use of self-regulated learning strategies. American Educational Research Journal, 23(4), 614-628.

Zimmerman, B. J., \& Martínez-Pons, M. (1988). Construct validation of a strategy model of student self-regulated learning. Journal of Educational Psychology, 80, 284-290.

Zimmerman, B. J., Greenberg, D., \& Weinstein, C. E. (1994). Self-regulation academic study time: A strategy approach. In D. H. Schunk \& B. J. Zimmerman (Eds.), Self-regulation of learning and performance: Issues and educational applications (pp. 181-199). Hillsdale, NJ: Lawrence Erlbaum. 